DANSKE

\section{FORSKNINGS- MILJØER}

Bo Jacobsen, Mikkel Bo Madsen og Claude Vincent: Danske forskningsmiljøer. En undersøgelse af universitetsforshningens aktuelle situation. Hans Reitzels Forlag, København 2001. 168 sider, kr. 175. Bo Jacobsen: Hvad er god forskning? Psykologiske og sociologiske perspektiver. Hans Reitzels Forlag, Kobenhavn. 2001. 156 sider, kr. 150.

$\mathrm{D}$ er er tale om to parallelt udgivne bøger. I den første præsenteres resultaterne af en undersøgelse med kvantitative interviews med 258 universitetsforskere i Danmark, suppleret med 25 kvalitative interviews. Det kvalitative materiale fremtræder fortrinsvis ved citater, som forfatterne dog i mange tilfælde ikke tør stå alene, hvorfor de ofte gentager indholdet lige efter med næsten samme ord. Tak, vi fangede det ellers i første omgang. Forskningsmiljø defineres i udgangspunktet som institutmiljø, men det viser sig $\mathrm{i}$ undersøgelsen, at mindre grupper på institutterne ofte er mere betydende for, hvordan forholdet til kollegerne erfares.

Forfatterne slår allerede $\mathrm{i}$ indledningen fast: "I undersøgelsen har vi konstateret klart positive og signifikante sammenhænge mellem forskningsmiljøets sociale og psykologiske dimensioner på den ene side og dets produktivitet og kvalitet på den anden" (s.10). De fortæller, at i "besvarelserne blev det helt overvejende betonet, at et godt forskningsmiljø indebarer fagligt samarbejde" (s.31, original kursiv), med stikord som adgang til diskussion, udveksling og inspiration. Tre fjerdedele af respondenterne giver en nogenlunde positiv bedømmelse af deres eget institutmiljø. Det hænger sammen med oplevelsen af fællesskab, gensidig accept og positiv vurdering af indbyrdes forskelle, god stemning, positiv vurdering af forskningens niveau og instituttets produktivitet, og positiv vurdering af institutledelsen. Disse sammenhænge lyder jo yderst plausible.

Men kan man nu vide, hvordan sammenhængene skal forstås? At generel positiv vurdering på ét punkt kan føre alt det andet med sig. Eller snarere at der er tale om forskellige udtryk for den samme 'generelle tilfredshed'? Forfatterne vælger forsigtigt (og klogt) det sidste: beskrivelserne viser forskellige træk af et godt forskningsmiljø. De peger på en positiv sammenhæng mellem stemning og forskningsoutput, men ikke på den nærliggende mulighed, at god/dårlig stemning simpelthen giver større tilskyndelse til at vurdere ens eget instituts forskning mere positivt/negativt (uden at den nødvendigvis er god/dårlig målt med andre alen). En jubel- hhv. kværulant-effekt? Nå, det kan næppe true den konklusion i undersøgelsen, at "også mere kontante og resultatorienterede dimensioner af forskningen kan fremmes, hvis man kan udvikle et godt socialt og fagligt milje" (s.61). At det modsvarer lektion 1 på ethvert leder- og teambuildingkursus i dag, gør det jo ikke mindre sandt og vigtigt.

Kønsperspektiver spiller ikke nogen stor rolle i undersøgelsen, som dog bl.a. "afkræfter det stereotype billede af lavtproducerende kvinder og arbejdsfanatiske mænd" (s.65):

De har samme lange arbejdstid (over 48 timer i gennemsnit), men mens mændene overvejende er tilfredse med balancen mellem arbejde og privatliv, er over halvdelen af kvinderne utilfredse med den. Det knyttes til en forskel i den generelle arbejdsglæde: knap halvdelen af de mandlige mod kun en fjerdedel af de kvindelige forskere er "særdeles glade" for deres arbejde (s.88).

Når der ses på de store linjer, er der langt imellem de overraskende resultater, hvis der overhovedet er nogen, men ikke desto mindre er det udmærket at få dokumentation i ord og tal for, hvad man ellers må nøjes med at påstå, som f.eks. at forskningsbaseret undervisning og forskningsfrihed er afgørende dele af forskernes erfaringer og idealer: uden disse intet universitet. Undersøgelsen peger også på, at forskerne ser en modsætning mellem på den ene side kortsigtet politisk styring og bevillingspraksis og på den anden side langsigtet opbygning af gode forskningsresultater og -miljøer. Ihukommende den seneste finanslovs tilfældige given med den ene hånd $\mathrm{og}$ tagen mere med den anden, og med mere styringsog evalueringsvrøvl i udsigt, er disse bekymringer kun blevet mere aktuelle. 
$\mathrm{B}_{t}^{\mathrm{o}}$ o Jacobsens Hvad er god forskning? er en bredt anlagt indføring, ikke i videnskabsteori og metode, men i de psykiske og sociale omstændigheder for, at forskning af høj kvalitet (og ikke bare i stor mængde) kan frembringes. Der er tale om fremragende formidling, men på bogens fả sider kommer vi vidt omkring; fra forskningens særlige væsen til ansættelseskonflikter, fra samspillet mellem intuition og analyse til mænds og kvinders forskellige vurdering af, hvem der er særligt gode forskere (kvinder peger på kvinder og mænd på mænd i den undersøgelse, der er fremlagt ovenfor).

Som læsningen skrider frem, bliver man noget utålmodig efter mere substantielle diskussioner. Den efterlysning kan dog også ses som udtryk for kvalitet: det er væsentligt stof, det her, og elementært vedkommende for enhver, der er involveret $\mathrm{i}$ universitetets verden. Udmærket som afsæt for en debat mellem kolleger om, hvordan vi hver især og i fællesskab har indrettet os med at bedrive forskning. Undertegnede ph.d.-studerende slugte nysgerrigt kapitlet om, "hvordan man lærer at forske" og dets generelle anbefaling af mesterlæremodellen.

Det første binds fokus på forskningsmiljøets betydning videreføres her, og der gås lidt mere i dybden med temaer som miljøets grundstemning og former for samarbejde, samvær og ledelse, og hvorfor det ikke er perifere, men centrale, faglige anliggender. Forskningsledelse beskrives som hverken administratorfunktioner (som nok dominerer i dag) eller ekstern management, men som en samling af ansvar for at fremme et godt forskningsmiljø og gode arbejdsprocesser. Det lyder som et konstruktivt bud. Fortæl os noget mere om det.

Alt $i$ alt er der tale om et par glimrende bøger at have på hylden for referencelitteratur i den diskussion om forskningens vilkår, som alt tyder på, vi făr mere af i de kommende år.

Steffen Jöhncke, ph.d.stipendiat Institut for Antropologi Københavns Universitet
BECOMING MODERN

Birgitte Søland: Becoming Modern. Young Women and the Reconstruction of Womanhood in the 1920s. Princeton University Press 2000.

$\mathrm{D}$ en 17-årige Edith Jørgensen blev i 1926 den første Miss Danmark, og hun vandt ikke konkurrencen på grund af sine kvindelige kurver, men på grund af et mere naturligt og barnligt, drengeagtigt udseende. Med drengepigen var et nyt kvindeideal kommet til verden til glæde for nogle men ikke for alle, for hvad var så forskellen mellem pæne damer og gadens piger? Som Ekstrabladets redaktør skrev, så var det svært for mænd at respektere kvinden, når hun "mødte os $\mathrm{i}$ form af en luder". Carla Meyer, som var formand for Den danske Husmoderforening, skrev et åbent brev til forretningsindehaverne, hvor hun anmodede dem om at ophøre med at udstille halvnøgne kvindekostumer. Den næste kamp stod om kvinders hår, det lange mod det korte - af nogle kaldet hottentothår. Ikke bare lignede disse kvinder aber; de ville også miste enhver mands attraktion og kunne se frem til et liv som gammeljomfruer og et liv i skallethed, lød truslerne. Visse arbejdspladser nægtede at ansætte kvinder, som havde tillagt sig den nye hårstil, men den var kommet for at blive. Moden og udseendet var en del af unge kvinders opgør med fortiden, såvel som udtryk for kvindelig modernitet ifølge Birgitte Sørland. Hendes bog Becoming Modern... handler 